\title{
Effects of Natural Environmental Conditions on the Ovarian Histometric Dynamics of Five Striped Squirrels (Funambulus pennanti)
}

\author{
Efectos de las Condiciones Ambientales Naturales sobre la Dinámica \\ Histométrica de Ovarios en la Ardilla de las Palmeras (Funambulus pennanti)
}

Sadia Rehman*; Mahmood-ul-Hassan*; Anas Sarwar Qureshi** \& Zeeshan Akbar****

REHMAN, S.; MAHMOOD-UL-HASSAN; QURESHI, A. S. \& AKBAR, Z. Effects of natural environmental conditions on the ovarian histometric dynamics of five striped squirrels (Funambulus pennanti). Int. J. Morphol., 34(1):262-267, 2016.

SUMMARY: The present study was designed to determine the morphological and histological variations in the female palm squirrel's reproductive organs which inhabit croplands of central Punjab. 16 specimens were collected from 3 different locations of Faisalabad district during different months in order to collect their ovaries samples in order to determine the breeding phenology of this species. Body weight and external body measurements were recorded. Two adult females were autopsied each month and their ovaries were extracted. Tissue were prepared by the tissue paraffin technique and stained by H\&E. Seasonal variations in the follicular size and shape were observed. Statistical analysis revealed that values of all parameters of ovaries were significantly $(\mathrm{P}<0.01)$ higher during peak folliculogenic phase (January to May) as compared to low folliculogenic phase (November-December). Three reproductive phases were observed according to follicular development i.e., quiescent period (November- December), recrudescence period (January) and peak reproductive phase (February-March). In conclusion of this study, different phases of sexual activities are determined which are controlled by seasonal variations. These variations are in accordance to different physical factors which influences gross anatomical and histological changes of ovaries and folliculogensis of female five-striped northern palm squirrel (Funambulus pennanti) for adjustments in breeding phenology.

KEY WORDS: Squirrels; Folliculogenesis; Ovaries; Season.

\section{INTRODUCTION}

Squirrels belong to Family scuiridae which is one of the largest and widespread mammalian taxa (Herror et al., $2003)$ i.e. the flying squirrels (Pteromyinae) and the nonflying squirrels (Sciurinae). They are well studied with reference to their morphological systematics, behavior and ecology (Steppan et al., 2003). Northern palm squirrel (Funambulus pennanti), is naturally found throughout southeast Iran, Pakistan, Nepal, India and perhaps adjacent Afghanistan (Nowak, 1999; Wilson \& Reeder, 2005; Thorington et al., 2005). In Pakistan it commonly occurs throughout Khyber-Pakhtunkhwa except in high mountainous regions and ranges from Kurram Valley through Kohat, Tank and Bannu and also in extensive sandhill desert areas in Thal, Tharparkar and Cholistan (Roberts, 1997). Key features for identification include five cream colored stripes on the back. Five longitudinal pale stripes are present on the darker dorsal side. The mid-dorsal stripe extends to the tail, and the lateral ones extend from ears to the tail's base. Two lateral ones are present on head: an indistinct one ranging from the ear to the eye, and a more distinct one extending from below the ear, passing below the eye, and onto the rostrum. It does not have the red mid-ventral stripe on the tail which is seen in the other related species (Prakash \& Kametkar, 1969).

Northern palm squirrel Funambulus pennanti is chirpy, highly mobile and agile and generally arboreal and forages extensively by quickly moving on the ground. Greenish brown fur with five longitudinal creamy stripes and wooly thick tail are the major morphological features of the species (Roberts; Yousefi et al., 2013). It is a semiarboreal and diurnal species which can adapt easily to every habitat and it can be found in subtropical and tropical dry deciduous forest, scrub lands, grass lands, urban areas, rural

\footnotetext{
* Department of Zoology, Wild Life and Fisheries, University of Agriculture, Faisalabad, Pakistan.

** Department of Anatomy, University of Agriculture, Faisalabad, Pakistan.

**** Department of Veterinary Biomedical Sciences, PMAS Arid Agriculture University, Rawalpindi, Pakistan.
} 
gardens, and introduced vegetation and plantations (Molur et al., 2005). It is a very common and well-recognized rodent pest of forest nurseries, kitchen garden and pomegranate fruits (Paunikar \& Ahmed, 2002). It causes severe losses in orchards and vegetable crops (Malhi \& Prasad, 1989) inflicting severe reduction in seed and seedling production, though of no economic significance as agricultural crop pest in Pakistan (Roberts). There is little information regarding its role in ecosystem, however, it is suggested that it may play a role in dispersing the seeds, providing food for birds of prey and pollinating some plants. Moreover, there is no information about predation of $F$. pennanti, but some raptors like golden eagle occur in the same region where $F$. pennanti lives, so they might be assumed as their predators. Some large sized snakes and other predators can also predate these squirrels. Cryptic coloration is also used as adaptation to avoid predation. These squirrels use senses of touch, sight, smell and auditory sense to perceive their environment, where sight, smell and touch are used to find food. Sound and visual display is used to communicate with the members of the species. Five-striped palm squirrels have sharp bird like calls. There are no evidences found for the use of pheromones for territorial marking or attracting the mates. They use both communication; visual and acoustic (Mitchell, 1979).

There is a seasonal change in body weight, in summer they lose some weight and are under stress, peaks in spring and at the end of monsoon. The environmental factors such as temperature, day-length and food availability etc. may have marked effects on the neuro-endocrine system which as a result can change immunity and reproduction. The five striped palm squirrels are wide-spread in their habitat preferences. These squirrels are living in elevation below 4,000 meters. These animals have been found in scrublands, grasslands, plantation and subtropical and tropical, dry deciduous forest. Its distribution in Pakistan seems to be directly related to irrigated cultivation (Roberts). As the fivestriped northern palm squirrel (Funambulus pennanti) is a seasonal breeder, so the climatic changes can modulate the breeding season. So this study was planned to determine the effects of seasonal variations on breeding phenology of this specie. This study also emphasizes areas where knowledge is lacking or incomplete, with the hope of fostering additional research on this exciting and fruitful area of squirrel biology.

\section{MATERIAL AND METHOD}

Experimental design: The study was conducted in Faisalabad district to investigate follicular development of female five striped palm squirrel, Funambulus pennanti. Three locations in Faisalabad district were selected for collection of squirrels. Squirrels were captured alive by one-way cage traps. Grains, corns, walnut, almond and peanut were used as bait to attract squirrels. From November 2013 to June 2014, these cages were placed at different sampling localities and occasionally checked if any squirrel trapped. The trapped squirrels were then transferred to a comfortable natural environment before autopsy. A total of twenty six specimens were collected during this study from three different locations.

Morphological Assessment: The exact species of each captured specimens was identified on the basis of external morphological features. The body measurements like head and body length, ear length, fore and hind limb length and different skull measurements of each specimen were taken before autopsy. The ovaries from individual squirrel were obtained and observed carefully for their gross and histological features after autopsy (Fig. 1).

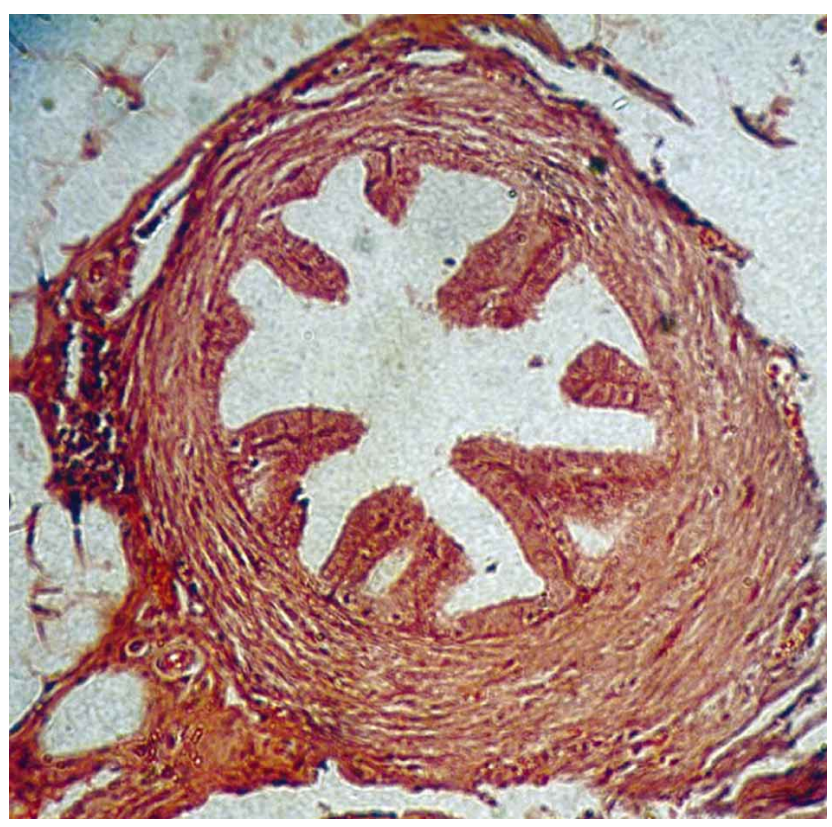

Fig. 1. Oviduct of female five-striped pal squirrel, $F$. pennanti captured, H \& E 20X.

Histometrical Analysis: Different slides of each ovary were prepared from Paraffin block technique. Photomicrographs of each ovary were captured using Nikon Optiphot 2 microscope at 20X. These photos were used to determine the diameter $(\mu \mathrm{m})$ of ovarian follicles of each ovary with the help of automated image analysis system Image $\mathrm{J}^{\circledR}$ version 1.47n (Research Services Branch, National Institute of Mental Health, Bethesda, Maryland, USA).

Statistical Analysis: To compare the means of parameters one way analysis of variance (ANOVA) was used and least significance difference (LSD) test helped to compare the group means at $5 \%$ level of significance. 


\section{RESULTS}

Seasonal morphological variations: Different morphological parameters like head to body length, ear length, tail length, hind foot length, basal length, condylobasal length, greatest skull length, nasal length, zygomatic breadth, palatal length, mandible length, interorbital breadth, postorbital constriction, mandible toothrow, maxillary toothrow, nasal breadth, biorbital breadth and palatal breadth were measured as indicated in Table I.

External body examination during different months: External body examination to access the pregnancy in all the female Funambulus pennanti squirrels was carried out to determine the condition of vagina and mammary glands that is indicated in Table II.

Monthly Variations in the Weight of Ovaries: The monthly variations in weight of ovaries of female five-striped palm squirrel, Funambulus pennanti, during different months. Mean weight of ovaries of pregnant females were highest (33.4 \pm 0.28$)$ most probably by the presence of corpus luteum. Follicular development was also active during pregnancy. Lowest mean ovarian weights were observed in November (10.8 \pm 0.57$)$, and June (17.2 \pm 0.98$)$. There is an increasing trend in ovarian weights from November to March
Table I. Grand mean $( \pm$ SEM) and range $(\mathrm{mm})$ of body and cranial measurements of the female five-striped palm squirrel, F. pennanti.

\begin{tabular}{lcc}
\hline Parameters & Mean \pm SD & Range \\
\hline HBL & $14.14 \pm 0.70$ & $13.8-14.8$ \\
T & $10.11 \pm 0.42$ & $9.8-10.4$ \\
HF & $3.91 \pm 0.28$ & $3.7-4.1$ \\
E & $1.41 \pm 0.14$ & $1.3-1.5$ \\
BL & $30.76 \pm 1.14$ & $29.98-31.60$ \\
CBL & $30.845 \pm 0.42$ & $30.54-31.13$ \\
GLS & $35.99 \pm 0.53$ & $35.58-36.33$ \\
NL & $9.01 \pm 0.13$ & $8.90-9.09$ \\
ZOB & $19.22 \pm 0.57$ & $18.93-19.75$ \\
PL & $16.38 \pm 0.62$ & $16.0-16.89$ \\
ML & $24.8 \pm 0.90$ & $23.13-24.41$ \\
IOB & $9.44 \pm 0.55$ & $9.06-9.84$ \\
POC & $16.25 \pm 1.01$ & $15.39-16.83$ \\
MT & $6.57 \pm 0.74$ & $5.96-7.02$ \\
MTR & $6.2 \pm 0.65$ & $5.66-6.58$ \\
NB & $4.08 \pm 0.43$ & $3.77-4.38$ \\
BOB & $14.12 \pm 0.34$ & $13.91-14.39$ \\
PB & $5.39 \pm 0.55$ & $5.16-5.94$ \\
\hline
\end{tabular}

$\mathrm{HBL}=$ head to body length; $\mathrm{E}=$ ear length, $\mathrm{T}=$ tail length; $\mathrm{HF}=$ hind foot length; $\mathrm{BL}=$ basal length; $\mathrm{CBL}=$ condylobasal length; $\mathrm{GLS}=$ greatest skull length; $\mathrm{NL}=$ Nasal length; $\mathrm{ZOB}=$ zygomatic breadth; $\mathrm{PL}=$ palatal length; $\mathrm{ML}=$ mandible length; $\mathrm{IOB}=$ interorbital breadth; $\mathrm{POC}=$ postorbital constriction; $\mathrm{MT}=$ mandible toothrow; $\mathrm{MTR}=$ maxillary toothrow; $\mathrm{NB}=$ nasal breadth; $\mathrm{BOB}=$ biorbital breadth; $\mathrm{PB}=$ palatal breadth.

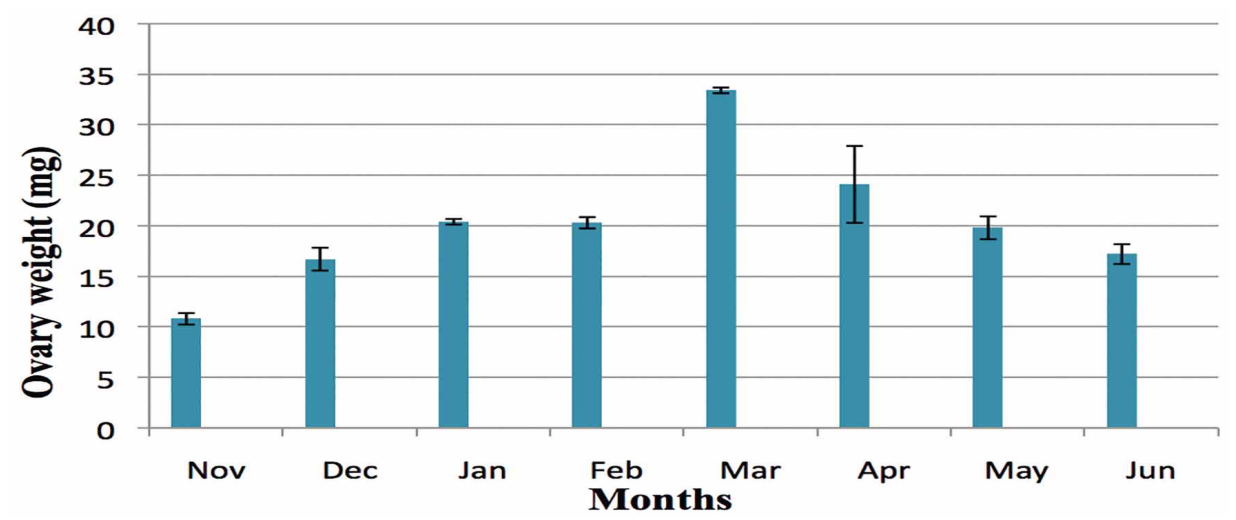

Fig. 2. Trends in weight of ovaries of female five striped palm squirrel $F$. pennanti, captured from Faisalabad District, during different months $(\mathrm{P}=0.02)$ in Nov- Dec while rest of months $(\mathrm{P}=0.01)$.

Table II. External body examination of female Funambulus pennanti captured from Faisalabad District during different months.

\begin{tabular}{lcccc}
\hline & \multicolumn{2}{c}{ Condition of Mammary glands } & \multicolumn{2}{c}{ Condition of Vagina } \\
\cline { 2 - 5 } Month & At start of month & At the end of month & At start of month & At the end of month \\
\hline November & Dry & Dry & Imperforated & Imperforated \\
January & Dry & Dry & Imperforated & Imperforated \\
February & Dry & Dry & Imperforated & Imperforated \\
March & Dry & Dry & Imperforated & Perforated \\
April & Dry & Dry & Perforated & Perforated \\
May & Lactating & Lactating & Perforated & Imperforated \\
June & Lactating & Lactating & Imperforated & Imperforated \\
& Lactating & Dry & Imperforated & Imperforated
\end{tabular}


(10.8 \pm 0.57 to $33.4 \pm 0.28$ ) and then from April to June there is a decline in ovarian weight $(24.1 \pm 3.8$ to $17.2 \pm 0.98)$ as indicated in Figure 2.

Table III. Size range of different ovarian follicles of female five-striped palm squirrel Funambulus pennanti captured from Faisalabad district.

\begin{tabular}{llc}
\hline \multirow{3}{*}{ Follicle Size } & & $\boldsymbol{\mu m}$ \\
\cline { 2 - 3 } & Primordial & $6-10$ \\
& Growing & $10-90$ \\
Oocyte Size & Graafian & $90-120$ \\
& Primordial & $5-7$ \\
& Growing & $15-30$ \\
Corpus Luteum & Graafian & $25-40$ \\
\hline
\end{tabular}

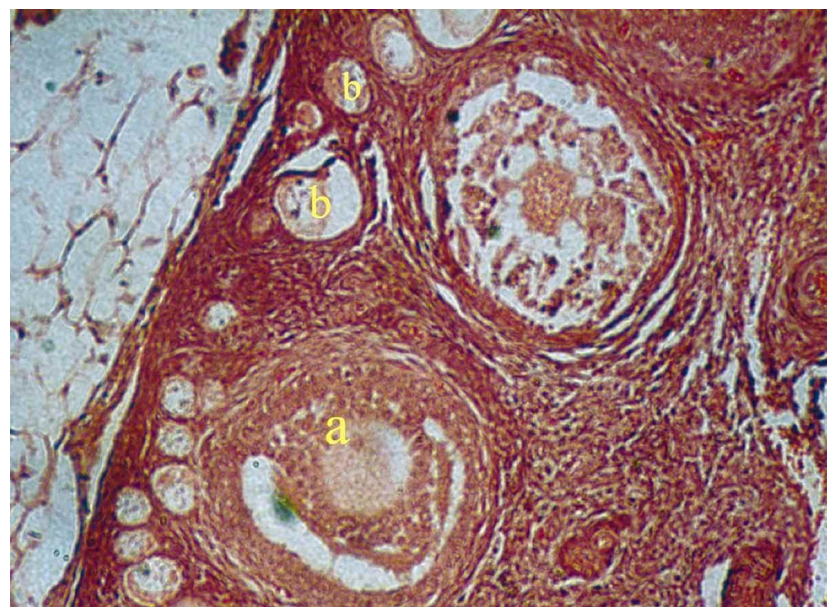

Fig. 3. Ovary of female five striped palm squirrel, F. pennanti. (a) secondary follicle, (b) primordial follicles. H \& E 10X.

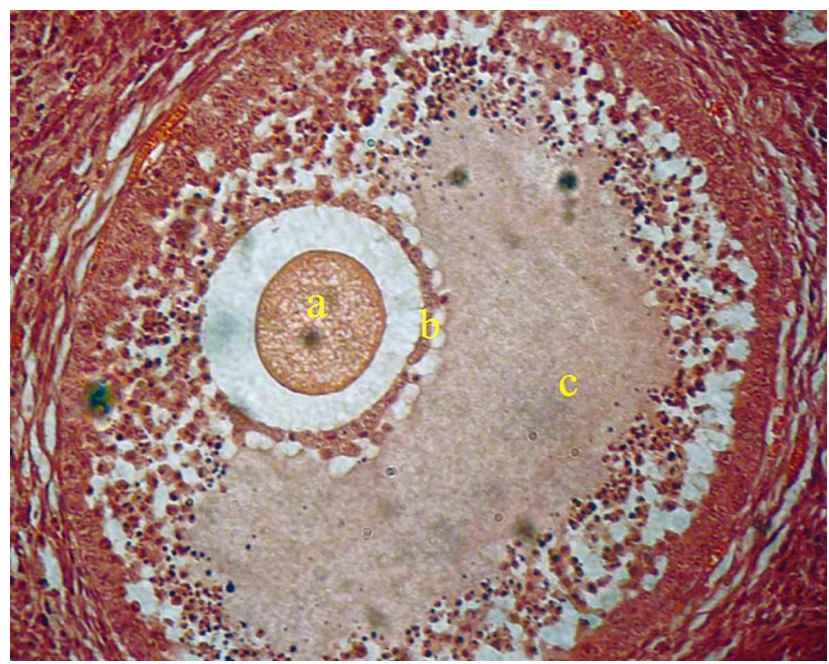

Fig. 4. Tertiary/Graafian ovarian follicle of female five striped palm squirrel, f. pennant (a) oocyte (b) granulosa cells (c) antrum. H \& E 20X.
Histometric measurements in ovaries: Table III represents the size range of different follicles of $F$. pennanti, from the monthly histological study of ovaries of each specimen. The size of primordial follicles was found to be $6-10 \mu \mathrm{m}$ while of growing follicles it was $10-90 \mu \mathrm{m}$ (Fig. 3). The tertiary or Graafian follicles had a size range of 90-120 $\mu \mathrm{m}$ (Fig. 4). Their oocyte sizes were also measured which were 5-7 $\mu \mathrm{m}$ for primordial, $15-30 \mu \mathrm{m}$ for growing and $25-40 \mu \mathrm{m}$ for tertiary follicles, while the size of corpus luteum was found to be $100-140 \mu \mathrm{m}$.

\section{DISCUSSION}

The reproductive system of female Funambulus pennanti comprises of two ovaries, a bicornuate uterus, uterine tubes, cervix and vagina. The ovaries are present on each side of the large intestine. Breeding habits show that the females breed from January till August. The females give birth to two to three babies from April to September and are from September to December they are sexually quiescent (Seth \& Prasad, 1969). From the data collected in the present study it is indicated that the females are sexually quiescent in November and December, that is, they do not mate or breed in this period and the mammary glands are dry and vagina imperforate. Ovarian activity was started in January and many of the primary follicles were observed in the ovaries. Two to three tertiary follicles were observed in the ovaries in February. Corpus luteum was observed in the ovaries of females collected in March and April and the vagina was perforated during this period but Mammary glands were dry. The females collected in the month of May had mammary glands in lactating state, that is, they were not dry, which suggested that it is the month of lactation. The ovarian samples in June suggested being in anestrus condition.

Period of Sexual Inactivity/ Quiescence: The data from the present study indicated the females to be sexually quiescent in November and December and the ovarian weights were very low ranging from $10.8 \pm 1.13$ to $16.7 \pm 0.57 \mathrm{mg}$. Pools of primordial follicles were observed in ovaries.

Period of Recrudescence: In the month of January, ovaries appeared to be in recrudescence and the weight of ovaries showed a sudden increase from $16.7 \pm 0.57 \mathrm{mg}$ in December to $20.4 \pm 0.58 \mathrm{mg}$ in January. Follicles were growing at many different stages in the ovaries and antral follicles were observed in the medullary region. The oocytes of these follicles were attached to the pole to the pole and surrounded by zona pellucida. 
Estrous Period: Females were sexually active in February and the ovarian weight observed $20.4 \pm 0.28 \mathrm{mg}$. Two tertiary follicles were observed in the ovary. There was one preovulatory follicle and many atretic follicles. The oocyte of the preovulatory follicle had a distinct zona pellucida and cumulus oophorus cells layer and there were two to three layers of granulosa cells. Theca interna and theca externa were also present.

Pregnancy Period: Most pregnancies occur in March and April. Data obtained from the present study also showed similar results with pregnancies found in March. Pregnancies were also observed in April. Corpus luteum was also seen in pregnant females and the numbers were two to three per ovary, but in non-pregnant females there were no corpora lutea seen, as according to the results weights of ovaries of pregnant females were highest, that is, $33.4 \pm 0.28 \mathrm{mg}$ which is presumed to be by the presence of corpus luteum. Follicular development was also taking place actively during pregnancy but they do not ovulate but undergo atresia after parturition which indicates that post-partum estrous does not occur in Funambulus pennanti.

Lactation Period: Most of the lactating females are found in March to November, with two peaks, one in April to May and other in July. In the present study one lactating female was caught in April and two in May. The mammary glands were found lactating. The ovarian weights of lactating females followed pattern similar to that of mature nonpregnant females ranging from $19.8 \pm 1.13$ to $24.1 \pm 0.98 \mathrm{mg}$. In the ovaries of lactating female corpus luteum and degenerating follicles were observed.

From the data collected during the course of present study in November 2013 to June 2014 following observations were made:

i.November and December might be called as sexually quiescent period in Funambulus pennanti female.

ii. January is the period of recrudescence and the preparation for next estrous.

iii. February and March is the estrous period, where February being the peak estrous period.

iv. Period from March to April observed pregnancies.

v. April and May are the months of lactation in F. pennanti.

Thus present study correlates well with the morphological and histological observations of ovaries in Indian palm squirrel, wild ground squirrel (Citellus dauricus Brandt) and European ground squirrels (Spermophilus citellus) (Seth \& Prasad; Millesi et al., 2008; Bao et al., 2014).

REHMAN, S.; MAHMOOD-UL-HASSAN; QURESHI, A. S. \& AKBAR, Z. Efectos de las condiciones ambientales naturales de la dinámica histométrica de ovarios en la ardilla de las palmeras (Funambulus pennanti). Int. J. Morphol., 34(1):262-267, 2016.

RESUMEN: El presente estudio fue diseñado para determinar las variaciones morfológicas e histológicas en los órganos reproductores de la ardilla de las palmeras que habita en las tierras de cultivo del centro de Punjab. Dieciséis muestras fueron recolectadas en 3 lugares diferentes del distrito de Faisalabad durante diferentes meses con el fin de obtener los ovarios y determinar la fenología reproductiva de esta especie. Se registraron el peso corporal y las medidas corporales externas. Se realizaron autopsias de dos hembras adultas cada mes y sus ovarios fueron extraídos. Se prepararon los tejidos por técnica de parafina y tinción H \& E y se observaron las variaciones estacionales en el tamaño y forma folicular. El análisis estadístico reveló que los valores de todos los parámetros de los ovarios fueron significativamente más altos durante la fase foliculogénica (enero a mayo), en comparación con la fase baja (noviembrediciembre) ( $\mathrm{P}<0,01)$. De acuerdo al desarrollo folicular se observaron tres fases reproductivas, el período de reposo (noviembre-diciembre), el período de recrudecimiento (enero) y la fase peak reproductiva (febrero-marzo). En conclusión las diferentes fases de las actividades sexuales definitivamente están controladas por variaciones estacionales. Estas variaciones se ajustan a diferentes factores físicos que influyen en los cambios anatómicos e histológicos de los ovarios y la folículogénesis de la ardilla hembra de las palmeras (Funambulus pennanti) para realizar ajustes en la fenología de su reproducción.

PALABRAS CLAVE: Ardillas; Foliculogénesis; Ovarios; Estación.

\section{REFERENCES}

Bao, L.; Li, Q.; Liu, Y.; Li, B.; Sheng, X.; Han, Y. \& Weng, Q. Immunolocalization of NGF and its receptors in ovarian surface epithelium of the wild ground squirrel during the breeding and nonbreeding seasons. Eur. J. Histochem., 58(2):2363, 2014.
Herror, M. D.; Castoe, T. A. \& Parkinson, C. L. Sciurid phylogeny and the paraphyly of Holarctic ground squirrels (Spermophilus). Mol. Phylogenet. Evol., 31(3):1015-30, 2003. 
Malhi, C. S. \& Parshad, V. R. Preharvest rodent damage to wheat in Punjab, India. FAO Quart. Newl.: Asia Pacific Plant Prot. Comm., 32:25-7, 1989.

Millesi, E.; Strauss, A.; Burger, T.; Hoffmann, I. E. \& Walzl, M. Follicular development in European ground squirrels (Spermophilus citellus) in different phases of the annual cycle. Reproduction, 136(2):205-10, 2008.

Mitchell, R. M. The sciurid rodents (Rodentia: Sciuridae) of Nepal. J. Asian Ecol., 1:21-8, 1979.

Molur, S.; Srinivasulu, C.; Srinivasulu, B.;Walker, S.; Nameer, P. O. \& Ravikumar, L. Status of South Asian Non-volant Small Mammals. Conservation Assessment \& Management Plan ( $C$. A. M. P.). Workshop Report. Coimbatore, Zoo Outreach Organization /CBSG South Asia, 2005. pp.618.

Nowak, R. Walker's Mammals of the World. $6^{\text {th }}$ ed. Baltimore, The Johns Hopkins University Press, 1999. pp.837-1936.

Prakash, I. \& Kametkar, L. R. Body weight, sex and age factors in a population of the Northern Palm squirrel Funambulus pennanti Wroughton. Ibid., 66:99-115, 1969.

Paunikar, S. \& Ahmed, S. I. Observation on infestation of five striped squirrel, Funambulus pennanti Wroughton, in the forest nurseries of arid and semi-arid zones. Rodent Newsl., 26(3):910,2002

Roberts, T. J. The Mammals of Pakistan. Karachi, Oxford University Press, 1997. pp.327-9.

Seth, P. \& Prasad, M. R. Reproductive cycle of the female fivestriped Indian palm squirrel, Funambulus pennanti (Wroughton). J. Reprod. Fertil., 20(2):211-22, 1969.

Steppan, S. J.; Storz, B. L. \& Hoffmann, R. S. Nuclear DNA phylogeny of the squirrels (Mammalia: Rodentia) and the evolution of arboreality from c-myc and RAG1. Mol. Phylogenet, Evol., 30(3):703-19, 2003.

Thorington Jr., R. W. \& Hoffmann, R. S. Family Sciuridae. In: Wilson, D. E. \& Reeder, D. M. (Eds.). Mammal Species of the World: A Taxonomic and Geographic Reference. $3^{\text {rd }}$ ed. Baltimore, Johns Hopkins University Press, 2005. pp.754-818.

Wilson, D. E. \& Reeder, D. M. Mammal Species of the World: A Taxonomic and Geographic Reference. $3^{\text {rd }}$ ed. Baltimore, Johns Hopkins University Press, 2005. pp.782.

Yousefi, S.; Izadian, M. \& Kheradpir, N. Survey of morphometric features of palm squirrel, Funambulus pennantii Wroughton, 1905 in Iran. Mun. Ent. Zool., 8(1):154-61, 2013.

\author{
Correspondence to: \\ Prof. Dr. Anas Sarwar Qureshi \\ Chairman \\ Department of Anatomy \\ University of Agriculture \\ Faisalabad \\ PAKISTAN
}

Tel: $\quad+9241920161-70 / 3102$

Fax: +92419200764

Mob. +92413006663702

Email: anas-sarwar@hotmail.com

Received: 16-04-2015

Accepted: 06-11-2015 